\title{
Osteoinduction Test of Anorthite by Human Mesenchymal Stem Cell Culture
}

\author{
Jônatas Sousa ${ }^{\mathrm{a}}$, Beatriz Luci Fernandes ${ }^{\mathrm{b} *}$, Carmem Lúcia Kuniyoshi Rebelatto ${ }^{\mathrm{a}}$, Fabiane Barchiki ${ }^{\mathrm{a}}$,
} Ana Paula Abud', Paulo Brofman ${ }^{\mathrm{a}}$, Simone de Oliveira ${ }^{c}$, Dorly Buchic, Carlos Roberto Fernandes ${ }^{\mathrm{b}}$

${ }^{a}$ Pontifical Catholic University of Paraná - PUCPR, Curitiba, Brazil

${ }^{b}$ Institute Grade of Basic Sciences - IGCB, Schroeder, Brazil

${ }^{c}$ Federal University of Paraná - UFPR, Curitiba, Brazil

Received: May 19, 2011; Revised: November 16, 2011

\begin{abstract}
In this work, adult stem cells of three volunteers were isolated, expanded and cultivated over samples of Anorthite in order to assess its osteoinductive capacity. Alkaline Phosphatase Analysis, ALP, was carried out at days 1, 7,14 and 21, and the results showed similar behavior between the volunteers considering the initial value of each. For volunteer 1, between day 14 and 21, the decreasing of ALP was remarkable in the wells containing MSC only and MSC+BIO, from 59.9 to 26.3 U.L. and from 63.3 to $38.1 \mathrm{U} . \mathrm{L}^{-1}$, respectively, suggesting that the biomaterial was able to induce osteoblast formations. This osteoinduction property could be evidenced by Citochemistry where MSCs did not produce crystals of Calcium Oxalate or Calcium Phosphate, osteoblast compounds, without being stimulated by a chemical inducer, lending to the conclusion that the differentiation of MSC into osteoblast when cultivated on Anorthite, occurred exclusively by its influence, strongly suggesting that it is osteoinductive.
\end{abstract}

Keywords: osteogenesis, biocompatible materials, stem cells culture on biomaterials.

\section{Introduction}

The autogenous bone grafting, obtained from the patient's own iliac crest is the most commonly used. However, clinical studies have been proven that there are some serious problems related to this procedure like morbidity and pain in the local of removed bone, long period of rehabilitation because of the additional incision and increased blood loss, risks of infection, vascular complications, low quantity and poor quality of the bone and prolonged time in the operating room ${ }^{1,2}$.

Alternative for autogenous grafting is allograft bone that is bone harvested from cadavers. Their successes are influenced by the host immunological system that can provoke rejection. Besides, these grafts present a wide variety and risks of diseases transmission ${ }^{3}$.

Those problems motivated the development of biomaterials to be used as synthetic scaffolds that must simulate the bone physicochemical environment and suffer degradation after complete their function of anchoring the new bone without, however, liberate toxic substances in the host organism².

In addition, preferentially, these materials have to be osteoinductors or have to induce bone formation and to be osteoconductor or have to allow the bone ingrowths ${ }^{4-6}$.

In order to stimulate the bone growths in porous and biodegradable scaffolds, they have been cultivated by stem cells, so the tridimensional graft promotes a

*e-mail: beatrizfernandes@igcb.org.br fundamental anchorage to cellular adhesion, proliferation and differentiation in osteoblasts ${ }^{7}$. The osteoblasts penetrate in the biomaterial interconnect porous forming a bridge required to fill up the bone defect ${ }^{8}$. The porous diameter must be between 100 and $200 \mu \mathrm{m}$ in order to allow the bone ingrowths and guarantee the nutrients supplying and blood vessels formations, essential to the tissue maintenance ${ }^{8,9}$.

The glassceramic Anorthite (patent MU 8702682-1) for clinical applications is composed mainly by silicon, aluminum and calcium in proportions covered by patent. The metallic oxides are mixed, melted and heat treated to obtain the final product. Since the Anorthite is biocompatible, biodegradable and has interconnected porous ${ }^{10}$, it is a suitable candidate for application in scaffolds for cells cultivation.

The aim of this work is to evaluate the osteoinduction capacity of the glassceramic Anorthite, cultivating it with human mesenchymal stem cells in order to evaluate the possibility of its application in scaffolds for bone ingrowth.

\section{Materials and Methods}

Flat circular pieces of Anorthite (BIO) with $55 \mathrm{~mm}$ diameter and $2 \mathrm{~mm}$ thickness were manufactured at the Grade Institute of Basic Sciences (IGCB, Schroeder, Brazil) using the conventional glassceramic manufacturing process, that is, components powder mixing, heating until fusion 
temperature obtaining glassy material, molding in stainless steel die, crystallization in controlled temperature rates forming the glassceramic material and controlled cooling. The flat pieces were cut in samples of, approximately, $5 \times 5 \mathrm{~mm}$ and sterilized in EtO.

The Mesenchymal Stem Cells (MSCs) were isolated from $5 \mathrm{~mL}$ aliquots of iliac crest bone marrow of three donors after their consent (Protocol $n^{\circ}$ 0002571/09/CEPPUCPR), procedure known as biological triplicate that provides enough data to qualify the osteoinduction capacity of Anorthite ${ }^{11}$. The isolation of stem cells was achieved by density gradient centrifugation at $1800 \mathrm{rpm}$ during $30 \mathrm{~min}$., in the presence of DMEM (Dullbeco's Modified Eagle medium - GIBCO-BRL) and 1.077 g.cm ${ }^{-3}$ Ficoll-Hypaque (Sigma Chemical). The mononuclear cells were seeded in $75 \mathrm{~cm}^{2}$ tissue culture flasks at a concentration of 106 cells. $\mathrm{ml}$ in DMEM, 15\% de FBS (Fetal Bovine Serum, GibcoTM Invitrogen, NY, USA) and $1 \%$ of antibiotic (penicillin, $100 \mathrm{U} . \mathrm{mL}^{-1}$ and streptomycin, $100 \mu \mathrm{g} \cdot \mathrm{mL}^{-1}$ ). After that, in order to expand the cells, sequential passages were made: when $80 \%$ confluence was achieved, the adherent cells were trypsinized (Trypsin-EDTA 05\%, 1×, GIBCO 25300), 10 minutes centrifuged at $1500 \mathrm{rpm}$ and homogenized with DMEM and FBS in culture flasks.

For the cells of each volunteer, the procedure was exactly the same. After the fourth passage, the cells were re suspended in DMEM and FBS medium and distributed between four plates occupying 16 wells of each plate. The
16 wells of the four plates of each patient were numbered and had the content showing in Table 1 that also shows the reasons for choice of wells content.

The content of plate I, of each volunteer, was used for Alkaline Phosphatase analysis (ALP) at the day 1. The content of the other plates, II, III and IV, were used for ALP and Cytochemistry at the days 7, 14 and 21. The culture maintenance was done by changing the medium three times a week.

In order to observe the interactions between the biomaterial and stem cells, it was analyzed the materials from the plates of the first patient only. The differentiation medium (DM) was added 48 hours after the culture has begun and this day was considered the first one. The DM composition was DMEM, $15 \%$ FBS, $1 \mu$ mol. $\mathrm{L}^{-1}$ dexamethasone, $10 \mathrm{mmol} . \mathrm{L}^{-1} \beta$-glycerol phosphate and $50 \mu \mathrm{mol} . \mathrm{L}^{-1}$ ascorbate.

The ALP was determined by a commercial kit and spectrophotometer at $405 \mathrm{~nm}$ wave length. Biomaterial and coverslip removed from the culture medium in the periods programmed were appropriated prepared for Cytochemical analysis, when cells stained with Alizarin Red.

\section{Results and Discussion}

The results of ALP enzymatic activity, mean of three data collection of each volunteer, are shown in Table 2 . The data were analyzed by qualitative method, since the intent was qualifying the Anorthite as osteoinductive material.

Table 1. Wells contents and main reasons it had selected.

\begin{tabular}{|c|c|c|}
\hline Well & Content & Reason \\
\hline $1 \mathrm{C}$ and $1 \mathrm{D}$ & $\mathrm{MSC}+\mathrm{BIO}$ & \multirow{2}{*}{$\begin{array}{l}\text { To compare the biomaterial effect on cellular morphology, growth and proliferation } \\
\text { and to verify if the biomaterial, by itself, promote MSC differentiation }\end{array}$} \\
\hline $3 \mathrm{C}$ and $3 \mathrm{D}$ & MSC only & \\
\hline 4C and 4D & $\mathrm{MSC}+\mathrm{BIO}+\mathrm{DM}$ & \multirow{2}{*}{$\begin{array}{l}\text { To compare the osteoblast differentiation capacity of MSC with and without } \\
\text { the presence of DM }\end{array}$} \\
\hline $6 \mathrm{C}$ and $6 \mathrm{D}$ & $\mathrm{MSC}+\mathrm{DM}$ & \\
\hline $3 \mathrm{~A}$ and $3 \mathrm{~B}$ & MSC only & \multirow{2}{*}{$\begin{array}{l}\text { To support the MSC viability and to compare the osteoblast differentiation } \\
\text { capacity of MSC with and without DM, in } \mathrm{pH} 4.2 \text { ( } 3 \mathrm{~A} \text { and } 6 \mathrm{~A}) \text { and in } \mathrm{pH} 7.0 \\
(3 \mathrm{~B} \text { and } 6 \mathrm{~B})\end{array}$} \\
\hline $6 \mathrm{~A}$ and $6 \mathrm{~B}$ & $\mathrm{MSC}+\mathrm{DM}$ & \\
\hline $2 \mathrm{C}$ and $2 \mathrm{D}$ & BIO only & \multirow{2}{*}{$\begin{array}{l}\text { To evaluate the wells content with biomaterial and DMEM only, with and without } \\
\text { DM and to compare these results with those found in wells } 1 \mathrm{C} \text { and } 1 \mathrm{D} \text {. }\end{array}$} \\
\hline $5 \mathrm{C}$ and $5 \mathrm{D}$ & $\mathrm{BIO}+\mathrm{DM}$ & \\
\hline
\end{tabular}

MSC $=$ Mesenchymal stem cell $; \mathrm{BIO}=$ Biomaterial DM = Differentiation medium.

Table 2. Results from ALP analysis.

\begin{tabular}{|c|c|c|c|c|c|}
\hline Well content & Volunteer & ALP day $1\left(\right.$ U.L $\left.^{-1}\right)$ & ALP day7 (U.L $\left.\mathbf{L}^{-1}\right)$ & ALP day $14\left(\right.$ U.L $\left.^{-1}\right)$ & ALP day $21\left(\right.$ U.L $\left.^{-1}\right)$ \\
\hline \multirow[t]{3}{*}{$\mathrm{MSC}+\mathrm{BIO}$} & 1 & 55.9 & 55.9 & 59.9 & 26.3 \\
\hline & 2 & 10.8 & 15.2 & 13.1 & 17.2 \\
\hline & 3 & 10.8 & 46.5 & 14.3 & 30.1 \\
\hline \multirow{3}{*}{$\begin{array}{l}\text { MSC only } \\
\text { (control group) }\end{array}$} & 1 & 58.6 & 58.6 & 63.3 & 38.4 \\
\hline & 2 & 13.5 & 17.5 & 21.6 & 24.6 \\
\hline & 3 & 13.5 & 31.0 & 58.9 & 38.1 \\
\hline \multirow[t]{3}{*}{ MSC+BIO+ DM } & 1 & 67.3 & 67.3 & 55.9 & 51.2 \\
\hline & 2 & 11.1 & 12.1 & 11.4 & 20.2 \\
\hline & 3 & 10.8 & 31.7 & 62.8 & 32.5 \\
\hline \multirow[t]{3}{*}{$\mathrm{MSC}+\mathrm{DM}$} & 1 & 57.2 & 57.2 & 60.6 & 59.9 \\
\hline & 2 & 14.2 & 14.8 & 12.1 & 16.7 \\
\hline & 3 & 14.2 & 33.9 & 53.3 & 60.0 \\
\hline
\end{tabular}


Although there are differences between the ALP values for the three volunteers, the qualitative analysis is valid because it is seeking for a final value higher than the initial one for each volunteer, indicating increasing of the osteoblast activity.

The ALP production by the MSCs isolated of the three volunteers showed similar behavior. Analyzing the results by cell culture period, in the day 1 , the volunteers 2 and 3 presented the same mean value of ALP. The high value presented by the volunteer 1 , could be caused by biliary dysfunction, presence of bone lesions or tumoral metastasis $^{12}$. Some studies suggest that age, gender and diseases can have an impact on osteogenic capacity of stem cells ${ }^{13}$.

The volunteers were cardiac, therefore, were taking medicines for cardiovascular functions. However, although some medicines make hard in vitro cell expansion, seems that they do not affect the functionality of cells ${ }^{14}$. Therefore, the medicines took by the volunteers, probably, were not responsible by the ALP different results.

The MSCs from the first volunteer showed no variation on the mean ALP value between days 1 and 7 . In the day 14 , only the well containing MSC+BIO+DM presented decreasing of ALP. The ALP is an osteoblast differentiation marker, and its quantity tends to decrease as the mineralization increases. So, the ALP value must rise from the day 1 to day 14 and decrease between day 14 and day 21 , in order to indicate a high rate of mineralization or osteoblast formation ${ }^{15}$. This behavior can be seen in data from the volunteer 1 (MSC only; MSC+DM) and the volunteer 3 (MSC only; MSC+BIO+DM).

Although bone formation is a complex process and not entirely understood, is known that cellular proliferation and osteoblast differentiation are almost excluding events, that means, increasing in cellular proliferation causes decreasing in ALP and increasing in osteocalcin related to the collagen mineralization ${ }^{15,16}$. The osteocalcin enzyme was not object of this study.

Interesting to note that, for the first volunteer, decreasing of ALP was remarkable in the wells containing MSC only and MSC+BIO. The wells containing DM maintained high values of ALP suggesting that, in this case, DM difficulties the cellular differentiation, delaying the collagen mineralization formed in the first stages of cell cultivation. Also, the data from day 14 and 21, suggest that the biomaterial with MSCs induced the collagen mineralization without the necessity of DM.

The second volunteer presented an increase of ALP at the day 7 in all wells, but it was more pronounced in the well containing MSCs only and MSC+BIO, showing that the DM did not interfere on the initial osteoblast differentiation, as, it was supposed to do. However, in wells containing MSCs only, ALP has continued to increase whereas, in wells with MSC+BIO, ALP decreased indicating cellular differentiation.

The third volunteer also showed a significant increase in the values of ALP in all wells, in day 7, being more pronounced in the well containing MSC+BIO. At day 14, only the well containing MSC+BIO showed a decrease in ALP value, indicating cell differentiation. The remaining wells showed pronounced increase of ALP compared to day 7, indicating osteoblasts formation. At day 21, the well containing $\mathrm{MSC}+\mathrm{BIO}$ had an increased value of ALP, as expected. The ALP of well containing MSC+BIO+DM remained with high values between days 1 and 21, indicating low cell proliferation.

The ALP values in the wells with MSC only from the second and third volunteers, at the day 1 , are closer to that considered normal and the DM presence affected cell proliferation, thereby increasing the period of differentiation. According to Ratisoontorn et al., 2005, (15) this behavior shows no progress towards the mineralization, that is, osteoblasts maturation.

Still regarding to the second and third volunteers, the ALP values variations, increasing between days 1 and 14 and decreasing between days 14 and 21 in the wells containing MSC only (control group), were expected for progress of osteoblasts differentiation. The wells containing MSC+BIO, unlike the control group, had increased ALP values between days 1 and 7, decreased between days 7 and 14 and increased between the days 14 and 21 . These variations can be explained only with further investigation in relation to chemical interaction between the biomaterial and stem cells, responsible for signals that induce cell differentiation and proliferation.

Pore size (macro, micro or nano), pore interconnectivity, adsorption and absorption properties of the biomaterial are critical parameters that should be considered in cell cultivation since they affect the interactions with MSCs, resulting in differences in biochemical markers values in relation to defaults or to those expected ${ }^{17}$

Interestingly, the behaviors for the wells with MSC only and $\mathrm{MSC}+\mathrm{BIO}$ in the plate for the first volunteer who had an initial ALP value above normal, were similar. This volunteer, with high phosphatase activity, helped cell differentiation and proliferation.

In general, the Anorthite was able to induce differentiation without the need of differentiation medium.

The Cytochemical Analysis was performed in the days 7, 14 and 21 in order to identify calcium crystals. In optical microscope images, these crystals appear as small dark spots around the cells, as shown in Figure 1, A to F.

Specifically, the alizarin red at $\mathrm{pH} 4.2$ detects Phosphate and Calcium Carbonate and, at pH 7.0, detects Calcium Oxalate (acicular crystals). These crystals are present in osteoblasts ${ }^{18}$. Calcium Phosphate participates in the mineralization process and Calcium Oxalate are metabolic end product $^{19}$.

Therefore, the Cytochemical Analysis becomes a powerful tool in evidencing differentiation of MSCs into osteoblasts, which might provide valuable finding in the cell differentiation process. Figure 1 shows the Cytochemistry at days 7, 14 and 21 in $\mathrm{pH} 4.2$ (left column) and $\mathrm{pH} 7.0$ (right column). In the control group, top right of all photos, it is possible to visualize the cells without Calcium Phosphate crystals. The Calcium crystals were formed when it was added the DM.

In coverslip cultures performed at $\mathrm{pH} 7.0$, it is possible to observe the formation of Calcium Oxalate crystals, dark spots scattered on the images, only in the presence of DM 


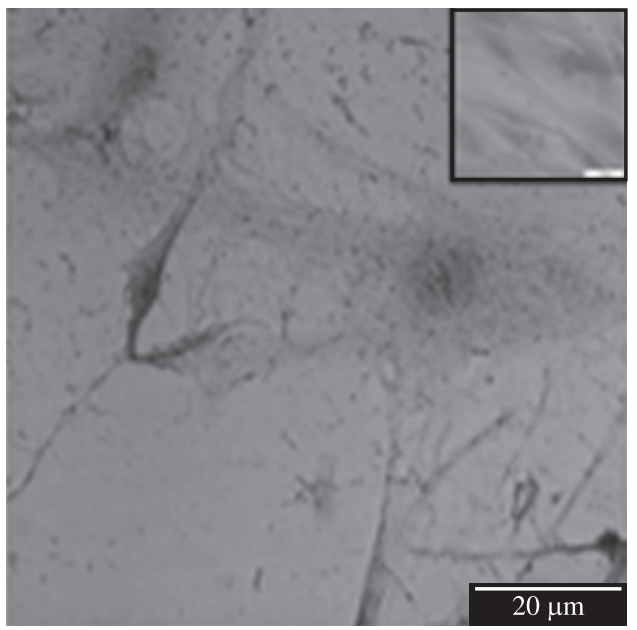

(a) Day $7, \mathrm{pH} 4.2$

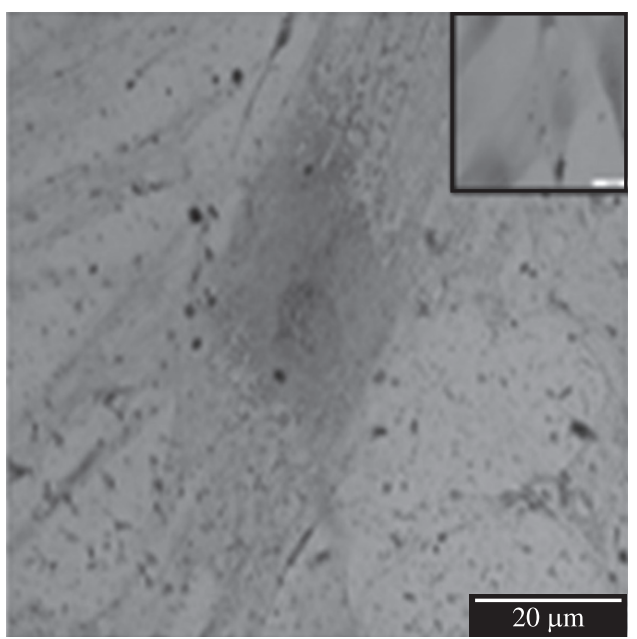

(c) Day $14, \mathrm{pH} 4.2$

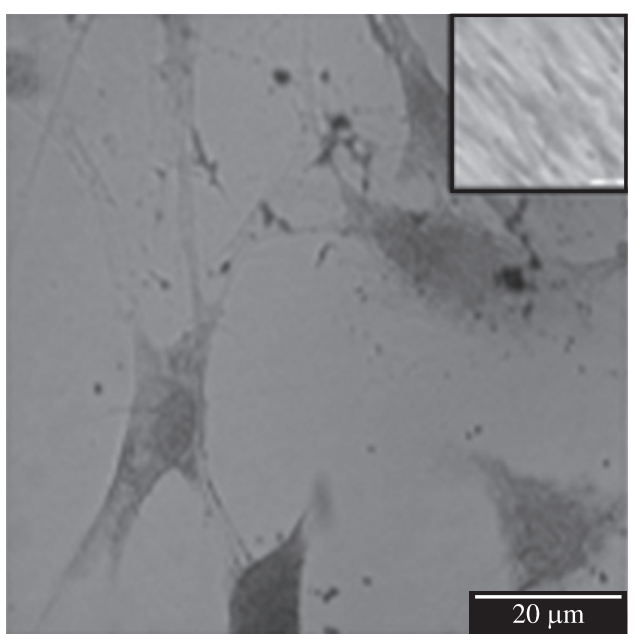

(e) Day 21, pH 4.2

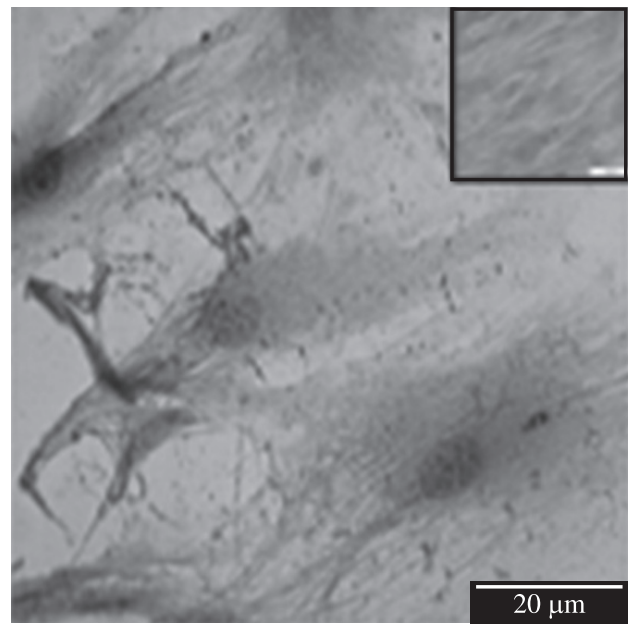

(b) Day 7, pH 7.0

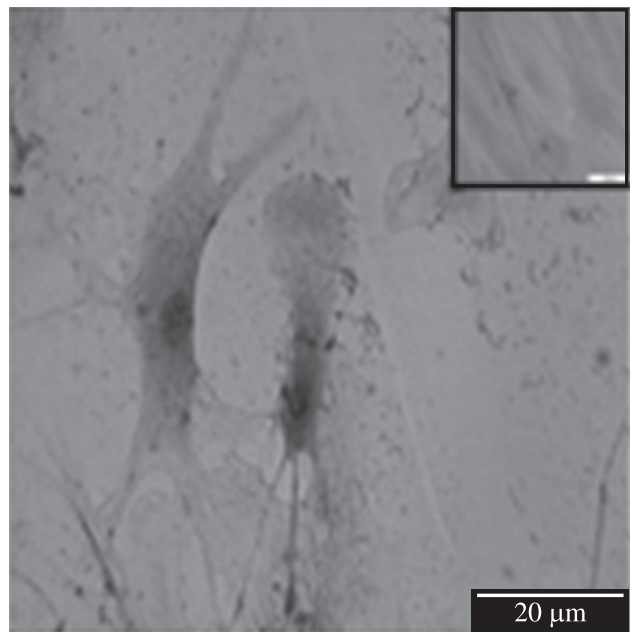

(d) Day 14, pH 7.0

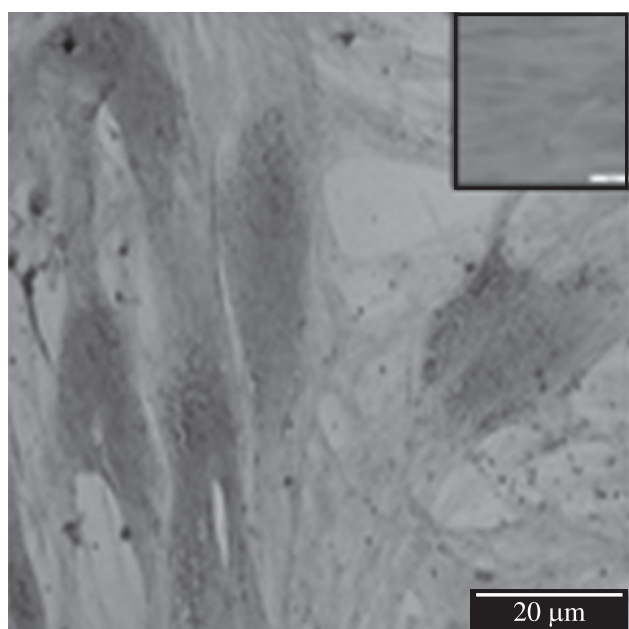

(f) Day 21, pH 7.0

Figure 1. Images from Cytochemical Analysis (400 X) of MSCs cultivation on coverslips in the presence of DM at a,b) day 7; c, d) 14; and e, f) 21. The control cells cultivated without DM are presented on top right of the images. The cells were stained with Alizarin S at a, c, e) $\mathrm{pH}$ 4.2; and b, d, f) $\mathrm{pH}$ 7.0, showing Calcium Phosphate and Calcium Oxalate crystals, respectively. MSC = Mesenchymal Stem Cell; DM = Differentiation Medium. 
(right column), independent of the day of cultivation. The same tendency was observed in cultures at $\mathrm{pH} 4.2$.

Therefore, MSCs did not produce crystals of Calcium Oxalate or Calcium Phosphate, compounds of osteoblasts, without being stimulated, in this case, by a chemical inducer. This leads to the conclusion that the differentiation of MSCs into osteoblasts when cultivated on Anorthite without the presence of DM, occurred exclusively by the influence of Anorthite. Therefore, the results of Cytochemical analysis strongly suggest that this biomaterial can induce differentiation of MSCs into osteoblasts, or even that Anorthite is osteoinductive.

\section{Conclusions}

According to the results, the Anorthite was able to induce differentiation without the need of differentiation medium what was evidenced by the cytochemistry findings. This behavior strongly suggesting that Anorthite is an osteoinductive biomaterial. No morphological or biochemical changes were observed, in the cultivation of MSCs on Anorthite, that could indicate cell injury proving that the material is biocompatible. The biocompatibility was also confirmed by the expansion and proliferation of the living cells on the material. Those evidences justify further investments to continue the research in in vivo studies. The cultivation of mesenchymal stem cells on biomaterial candidate for applications in the medical field proved to be a key method to determine the success of the biomaterial before clinical trials.

\section{Acknowledgement}

The authors thanks to CNPq for financial support.

\section{References}

1. Pinheiro TC, Santos FFC, Shirane HY and Cunha MR. Implantes de hidroxiapatita em falhas ósseas produzidas no fêmur de ratos submetidos ao tabagismo passivo. Revista Brasileira de Ortopedia. 2008; 43(10):433-441. http://dx.doi. org/10.1590/S0102-36162008001000003

2. Porter JR, Henson A and Popat KC. Biodegradable poly (E-caprolactone) nanowires for bone tissue engineering applications. Biomaterials. 2009; 30:780-788. PMid:19012962. http://dx.doi.org/10.1016/j.biomaterials.2008.10.022

3. Kamitakahara M, Ohtsuki C and Miyazaki T. Behavior of ceramic biomaterials derived from tricalcium phosphate in physiological condition. Journal of Biomaterials Applications. 2008; 23:197-212. PMid:18996965. http:// dx.doi.org/10.1177/0885328208096798

4. Patel MM and Catalano LW. Bone graft substitutes: Current uses in hand surgery. JHS. 2009; 34:555-556.

5. Eagan MJ and Mc Allister DR. Biology of allograft incorporation. Clinical Journal of Sport Medicine. 2009; 28:203-214. http:// dx.doi.org/10.1016/j.csm.2008.10.009

6. Sousa RC, Lobato JV, Mauricio AC, Hussain NS, Botelho $\mathrm{CM}$, Lopes MA et al. A clinical report of bone regeneration in maxillofacial surgery using bone like synthetic bone graft. Journal of Biomaterials Applications. 2008; 22):373-385.

7. Zhang ZY, Teoh SH, Chong WS, Foo TT, Chng YC, Choolanim $\mathrm{M}$ et al. A biaxial rotating bioreactor for the culture of fetal mesenchymal stem cells for bone tissue engineering. Biomaterials. 2009; 30(14):2694-2704. http://dx.doi. org/10.1016/j.biomaterials.2009.01.028

8. Khong L. Preparation and characterization of a multilayer biomimetic scaffold for bone tissue engineering. Journal of Biomaterials Applications. 2007; 22:223-239. http://dx.doi. org/10.1177/0885328206073706

9. Jones AC, Jonesa AC, Arnsa CH, Hutmacherb DW, Milthorpec BK, Shepparda AP et al. The correlation of pore morphology, interconnectivity and physical properties of 3D ceramic scaffolds with bone ingrowth. Biomaterials. 2009; 30:1440-1451. http:// dx.doi.org/10.1016/j.biomaterials.2008.10.056

10. Fernandes BL, Colpo JC, Manffra EF and Nohama P. Biocompatible glassceramic applied in drug release system. Revista Brasileira de Engenharia Biomédica. 2006; 24(1):33-37.

11. Smith GW and Rosa GJM. Interpretation of microarray data: trudging out of the abyss towards elucidation of biological significance. Journal of Animal Science. 2006; 85(E Suppl):E20-E23.

12. Henry JB. Diagnósticos clínicos e tratamento por métodos laboratoriais. 20th ed. São Paulo: Manole; 2008. 1670 p.

13. Ciapetti G, Ambrosio L, Marletta G, Baldini N and Giunti A. Human bone marrow stromal cells: In vitro expansion and differentiation for bone engineering. Biomaterials. 2006; 27(36):6150-6160. http://dx.doi. org/10.1016/j.biomaterials.2006.08.025

14. Lanza R. Handbook of Stem Cells. Elsevier Academic Press; 2004. v. 2: Adult and Fetal Stem Cells, p. 13-16, 301-304.

15. Ratisoontorn C, Seto ML, Broughton KM and Cunningham ML. In vitro differentiation profile of osteoblasts derived from patients with Saethre-Chotzen syndrome. Bone. 2005; 36(4):627-634. http://dx.doi.org/10.1016/j. bone.2005.01.010

16. Galli C, Guizzardi S, Passeri G, Martini D, Tinti A, Mauro $\mathrm{G}$ et al. Comparison of human mandibular osteoblasts grown on two commercially available titanium implant surfaces. Journal of Periodontology. 2005; 76(3):364-372. http://dx.doi. org/10.1902/jop.2005.76.3.364

17. Kasten P, Voguel J, Beyen I, Weiss S, Niemeyer P, Leo A et al. Effect of platelet-rich plasma on the in vitro proliferation and osteogenic differentiation oh human mesenchymal stem cells on distinct calcium phosphate scaffolds: the specific surface area makes a difference. Journal of Biomaterials Applications. 2008; 23(2):169-188. http:// dx.doi.org/10.1177/0885328207088269

18. Saldaña L, Sanchez-Salcedo S, Izquierdo-Barba I, Bensiamar F, Munuera L, Vallet-Regi M et al. Calcium phosphate-based particles influence osteogenic maturation of human mesenchymal stem cells. Acta Biomaterialia. 2009; 5(4):1294-1305. http:// dx.doi.org/10.1016/j.actbio.2008.11.022

19. Strzeleckl T and Menon M. The uptake of oxalate by rat liver and kidney mitochondria. Journal of Biomaterials Applications. 1986; 261(26):12197-12201. 